\title{
A DÉL-DUNÁNTÚL MINT A MAGYAR MAKROREGIONÁLIS SZERKEZET EGYIK ELEME
}

\author{
(South Transdanubia as an Element of the Hungarian \\ Macro-regional Structure)
}

Elốszó

Az elmúlt évtizedben az Európai Közösségben a területfejlesztésnek és tervezésnek egy többszintũ területi struktúrája épült ki, melynek tényleges müködését megfelelõ intézményhálózat és jelentôs pénzügyi alapok is biztosítják. E rendszeren belül - a mi fogalmaink szerinti - makroregionális szint egyre komolyabb hatalmi, gazdasági és mind határozottabban külpolitikai szerepet is játszik. A közvetlen regionális részvétel a nemzetközi területi munkamegosztásban jelentõs gazdasági elõnyökkel járt mind regionális, mind nemzeti, mind szupranacionális szinteken.

A Magyarország és az Európai Unió közötti társulási szerzôdésnek célja - többek között - , hogy:

- ,új szabályokat, politikát és gyakorlatot létesítsen, amelyek Magyarországnak a Közösségbe történõ integrációja alapját képezik";

- ,a társulás ténylegessé tételét szolgáló, megfelelô intézményeket hozzon létre’" (1994. évi I. tv. 1. cikk).

A társulási szerzôdésben külön cikk (87.) foglalkozik a regionális fejlesztéssel. Több intézkedést irányoz elô a regionális fejlesztés és a földhasználat tervezése ${ }^{1}$ területén.

Az Unió tagállamai a nemzetközi összehasonlíthatóság érdekében minden országban a régiók három szintũ hierarchikus rendszerét hozták létre (NUTS). E struktúrának a DélDunántúl bizonyosan egyik eleme lesz, viták legföljebb a kiterjedését tekintve lehetnek. Általában és tradicionálisan Baranyát, Somogyot, Tolnát és Zalát sorolják a Dél-Dunántúlhoz. Az önkormányzatok vezetôit megkérdezve önálló regionális identitásként jelenik meg a balatoni (közép-dunántúli) régió és egy nyugat-dunántúli régió is. Amennyiben valóban létrejönne egy nyugat-dunántúli/magyarországi régió, akkor Zala bizonyára oda tartozna.

A társulási szerzôdésnek megfelelôen a csatlakozáshoz való felkészülés során:

1) Megnyugtatóan rendezni kell a területfejlesztés törvényi szabályozása körül kialakult vitás kérdéseket. ${ }^{2}$

2) Az európai alapelvekre építve, a magyar sajátosságoknak megfelelōen ki kell dolgozni a hosszú távra érvényes - több parlamenti ciklust kiszolgáló - területfejlesztési stratégiát és a kormányzat négy évre vonatkozó területi politikáját; 
3) Végre kell hajtani a területi statisztika reformját, új, többszintũ területi információs rendszert kell kialakítani. A regionális centrumokban meg kell teremteni az EU dokumentációs bázisokat és információs rendszereihez illeszkedô központokat. ${ }^{3}$

4) Mindez azt is jelenti, hogy elố kell készíteni a hatalom területi decentralizálását, azaz ki kell alakítani a makroregionális rendszereket, meg kell találni a hazai intézményrendszernek megfelelõ formát és meg kell kezdeni ezen a szinten (is) a fejlesztési koncepciók, a területi tervek készítését.

$\mathrm{Az}$ európai integrációtól függetlenül a nemzetközi területi munkamegosztásba való mind eredményesebb bekapcsolódás érdekében is sürgôs feladat, hogy a regionális szint kikristályosodjék és a magyar régiókra hosszú távú programok készüljenek. A kérdés az, hogy milyen típusú tervet, és ki készítsen?

A területi tervezésrôl vallott nézetek - Kelet- és Nyugat-Európában egyaránt - szorosan kapcsolódtak az állam szerepérôl kialakult képhez. A II. világháború után az államtól és helyi szervezeteitõl várták el a szociális/jóléti folyamatok ellenôrzését, aminek középpontjában a közösségi intézmények, a lakáskérdés, a hálózati infrastruktúra stb. tervezése állt. Átfogó hosszú távú ,,blue-print” típusú tervek álltak a végrehajtás szolgálatába. A hetvenes évektôl kezdve egyre nôtt az elégedetlenség e tervezési módszerekkel és dokumentumaikkal szemben. A megújult (?) tervezési folyamat sokkal inkább ,,döntés-orientált'” volt, a területi tervek kevésbé törekedtek az ,,ésszerũ" területfelhasználásra, inkább a közösségi döntéshozatal koordinálását segítették. Jelenleg piacorientált területi tervekre van szükség, amely legfeljebb csak eszközeiben hasonlít a hatvanas-hetvenes évek terveihez, és annak ellenére, hogy sokat merít a ,döntésorientált" tervezési gyakorlatból, mégsem az érdekcsoportokra és koordinációra koncentrál elsôsorban, hanem a versenyre és a sajátos célcsoportokra.

A lassan változó területi struktúrákkal a magántôke mint adottságokkal számol és a saját parciális célja elérése során, nem tudatosítva módosítja csak azokat. Ha e másodlagos következmények esetleges kedvezôtlen hatásait mérsékelni akarjuk, akkor más szinten kell számba venni e döntések területi következményeit, szükség esetén hatni kell rájuk, mert egyrészt ezeknek negatív társadalmi hatásai is lehetnek, másrészt e trendek pozitív befolyásolása a magántõkének is érdeke, hiszen ezek a magántôke megtérülésére hatnak. E feltételrendszer alakítja a beruházási döntéseket, ami megváltoztatja a térbeli struktúrákat. Tehát, mivel az egyes vállalatok nem veszik számba döntéseik területi konzekvenciáit, a gazdaság szempontjából pedig nem mindegy a gazdálkodás regionális háttere, ezért a kormánynak és az önkormányzatoknak kell rendelkezniük hosszú távú stratégiával a térbeli folyamatok és struktúrák alakítására.4

E felismerések következtében több szálon futnak a dél-dunántúli regionális vizsgálatok. Elsôként a régió megyéinek és néhány településének vezetôi, valamint a térség más döntéshozói kezdeményezték egy átfogó regionális program készítését. Regionális középszint hiányában (a programnak nem volt gazdája: megrendelô, végrehajtó stb.) létrehozták a Dél-Dunántúli Regionális Fejlesztési Alapítványt. Ez jelentheti - a jelen- 
legi jogi keretek közötti kényszermegoldásként - a majdani dél-dunántúli intézmény (pl. regionális tanács) csíráját.

A kormány, miután a legsúlyosabb helyzetben lévõ megyékre készíttetett területfej lesztési koncepciókat, majd az Alföld egészének területfejlesztési gondjait is áttekintette, ugyancsak készített egy dél-dunántúli területfejlesztési koncepciót, amelynek segítségével elsôsorban az állami szervek számára kíván feladatokat meghatározni.

A régióra vonatkozó elôzetes vizsgálatok azt mutatták, hogy a dél-dunántúli koncepció vezérfonala - legyen az alulról épitkezố vagy a kormányzati munkát segítõ - ma a v'ersenyképes gazdasági szerkezet területi feltételrendszerének a meghatározása kell, hogy legyen. Ehhez nélkülözhetetlen elemzési módszer az európai régiókkal való összevetés. A hazai regionális elemzésekben eddig ritkán alkalmazott európai összehasonlítás több szempontból is hasznos lehet. Egyrészt megadja a régió helyét az európai gazdasági erôtérben. Az európai régiók adatainak ismeretében meghatározhatók azok a térségek, amelyeknek a strukturális és ellátottsági mutatói a leginkább hasonlítanak a dél-dunántúliéhoz, és ezek fejlódési pályái, regionális fejlesztési stratégiáik és azok megvalósítási tapasztalatai fontos segítséget adhatnak a dél-dunántúli stratégia kialakításához. Másrészt az összehasonlítás eredményei hasznosíthatóak a nemzetközi együttmũködésben.

A TÉT-nek ebben a tematikus számban - többek között - e munkákban közremũködốk tanulmányaiból közlünk néhányat. Az érdeklõdés felkeltéséért felvillantunk az eddig készült vizsgálatokból néhány megállapítást, amely segíthet a Dél-Dunántúl hiteles portréjának felvázolásában.

Az európai gazdasági erôtér súlypontja Magyarország számára kedvezôen, a korábbiakhoz képest keletebbre a dél-német és észak-olasz tartományok felé helyezôdik át. Ezzel Dél-Dunántúl geoökonómiai helyzete javul, némileg ellensúlyozva a geopolitikai helyzet - remélhetốen - átmeneti romlását.

$\mathrm{Az}$ Európa legnagyobb forgalmi-közlekedési folyosóitól távol fekvô régió Európa sajátos félperifériája. E helyzeten kardinálisan változtatni csak az EU-tagság elnyerése után a közösségi alapok anyagi támogatásával lehetséges. Más periférikus régiókhoz hasonlóan elmaradott a Dél-Dunántúl közlekedési és kommunikációs infrastruktúrája ${ }^{4}$, de az ipari és tercier szektor foglalkoztatottainak az aránya azokénál magasabb, így nem annyira az iparosítás, mint a szerkezetátalakítás a fố tennivaló.

A régió országon belüli helyzete több tekintetben átlagos: mind a teljesítménye, mind az új típusú gazdasági szervezetek és innovációk terjedése vonatkozásában elmarad a központi és észak-dunántúli régió mögött, de megelôzi Észak-Magyarországot és az Észak-Alföldet.

A gazdaság- és iparszerkezet csak lassan változik - inkább a hagyọmányos termelés leépülése jellemezte az elmúlt éveket, mint új tevékenységek megjelenése, és csak mérsékelt elmozdulás volt tapasztalható az aktív keresôk foglalkoztatási ágak szerinti megoszlásában. A gazdaság a jelenlegi bázison nem fejlôdhet tovább, hanem egy merốben új struktúrára van szükség ${ }^{5}$. Ennek kialakulását, a piac által való kitermelōdését nehezí- 
ti, hogy fejletlenek a termelõ és üzleti szolgáltatások, gyenge a $K+F$ tevékenység és kedvezôtlen a felsõoktatás szerkezete. Gyártás- és gyártmányfejlesztés hiányában érthetô, hogy kicsi a nemzetközileg piacképes termékek aránya, így az országban itt a legmérsékeltebb az exportorientáció. Az exportált termékek arányát tekintve Baranya és Tolna megye az utolsó a megyék rangsorában.

Az ÁVÜ kezelésében levõ gazdasági társaságok privatizációja lassan halad a régióban. A privatizációs szint 1993 végén Baranyában 54,8\%, Somogyban 44,2\%, Tolnában $36,5 \%$, és Zalában a legkedvezóbb pozíciójú megyében $83,4 \%$ volt.

A mezôgazdaságban a földek magánosítása mikrokörzetenként jelentốsen eltérõ mértékũ. Míg Tolna nagyobb hányadán a kárpótlási árveréseken eladott földek aránya már ez év elején 33\% körül alakult, addig a baranyai átlag ennek felét sem érte el, s pl. Csurgó és Marcali körzetében $9 \%$ alatt maradt. Kisebb az elmozdulás a termékszerkezet korszerúsítésében. A régió alig alkalmazkodott az EU-kereslethez.

$\mathrm{Az}$ idegenforgalomban is csak nagyon csekély volt a minõségi javulás, és nem történt meg az önmagukban szerény vonzerôt képviseló kínálati elemek integrált piacosítása.

A régió erôsen hierarchizált településszerkezete sajátos területfejlesztést igényel. Az egységes regionális fejlesztés szük körben járhat eredménnyel, inkább a hasonló adottságú kistérségek összefogásán alapuló fejlesztési programok javasolhatóak.

Faragó László

\section{Jegyzetek}

1 Értsd: területrendezés.

Egy területfejlesztési törvény gyors meghozatalára megvan minden remény, mert a kormánykoalíció mindkét pártjának programjában szerepelt e törvény meghozatalának szükségessége. Ezt rá lehetne építeni az MTA Regionális Kutatások Központjának intézményhálózatára.

A telekommunikációs hálózat fejlettsége hazai mércével átlag feletti, de még ez is tragikusan alacsony nemzetközi összehasonlitásban.

Ez megnehezíti a ma oly divatos szerves fejlôdés manifesztálódását. 